\title{
MODEL PEMBERDAYAAN MASYARAKAT MELALUI POLA MAGANG TRADISIONAL DALAM UPAYA PENINGKATAN WIRAUSAHA MASYARAKAT
}

\author{
Adang Danial', Yus Darusman², Mustakim³, Wiwin Herwina ${ }^{4}$ \\ ${ }^{1}$ Fakultas Keguruan dan IImu Pendidikan Universitas Siliwangi \\ email: adangdanial@unsil.ac.id \\ ${ }^{2}$ Fakultas Keguruan dan IImu Pendidikan Universitas Siliwangi \\ email: yusdarusman@unsil.ac.id \\ ${ }^{3}$ Fakultas Keguruan dan IImu Pendidikan Universitas Siliwangi \\ email: mustakimunsil@gmail.com \\ ${ }^{4}$ Fakultas Keguruan dan IImu Pendidikan Universitas Siliwangi \\ email: wiwinherwina@unsil.ac.id
}

\begin{abstract}
Problema lower literacy rates in Sub Cipawitra Mangkubumi District of Tasikmalaya impact on unemployment. Unemployment is a problem that requires a special close attention. The unemployment rate in over productive (aged 15 years and above) will have an impact on the increasing number of criminal, immoral, and illegal. The purpose of community service is the creation of a model of community empowerment in the field of sewing business, increased knowledge, skills and attitudes in entrepreneurship. In collaboration with community service Courses and Training Institute (CGC) Anugrah Pratama and Forums Community Activity Center (CLC) Tasikmalaya. Method of implementation of community service uses two stages, among others: the preparation phase and implementation phase. During the implementation phase includes four stages include: identification of skills learned, the implementation phase, the assessment phase, and the follow-up phase. The results of community service activities can create new entrepreneurs in the sewing business.

Keywords: community empowerment, traditional apprenticeship patterns, community entrepreneurship.
\end{abstract}

\begin{abstract}
ABSTRAK
Problema rendahnya angka melek huruf di Kelurahan Cipawitra Kecamatan Mangkubumi Kota Tasikmalaya berdampak pada banyaknya pengangguran. Pengangguran merupakan suatu masalah yang memerlukan perhatiaan khusus. Tingkat pengangguran pada usai produktif (usia 15 tahun ke atas) akan berdampak pada semakin banyaknya kriminalitas, asusila, dan tindakan melanggar hukum. Tujuan pengabdian kepada masyarakat ini adalah terciptanya model pemberdayaan masyarakat pada bidang usaha menjahit, peningkatan pengetahuan, keterampilan, dan sikap dalam berwirausaha. Pada pengabdian masyarakat ini bekerjasama dengan Lembaga Kursus dan Pelatihan (LKP) Anugrah Pratama dan Forum Pusat Kegiatan Masyarakat (PKBM) Kota Tasikmalaya. Metode pelaksanaan kegiatan pengabdian kepada masyarakat ini menggunakan dua tahapan antara lain: tahap persiapan, dan tahap pelaksanaan. Pada tahap pelaksanaan meliputi empat tahap antara lain: identifikasi jenis keterampilan yang dipelajari, tahap pelaksanaan, tahap penilaian, dan
\end{abstract}


tahap tindak lanjut. Hasil kegiatan pengabdian kepada masyarakat dapat mencetak wirausaha baru dalam bidang usaha menjahit.

Kata kunci: pemberdayaan masyarakat, pola magang tradisional, wirausaha masyarakat.

\section{PENDAHULUAN}

Pengetahuan dan keterampilan merupakan modal didalam mengembangkan kemampuan dan kecakapan manusia. Manusia sebagai makhluk sosial yang saling membutuhkan interaksi dengan manusia yang lain. Dalam kehidupan sehari-hari manusia juga mendapat jukukan sebagai zoon politicon (makhluk yang hidup berkelompok) mengandung arti bahwa antara sesama manusia menginginkan hubungan dengan orang lain dalam kehidupan sehari-hari.

Kehidupan dimasyarakat pada era saat ini, tidak akan lepas dari pengaruh budaya. Dengan budaya masyarakat dapat hidup harmonis dan saling menjaga hubungan baik. Karena budaya dimasyarakat yang sudah berkembang dan terpatri pada aktivitas sehari-hari dimasyarakat, serta merupakan suatu sistem sosial yang menjadi dasar masyarakat dalam berpijak untuk menjalani kehidupan. Kehidupan masyarakat tidak akan lepas dari nilainilai agama, aspek sosial, kesehatan, dan kehidupan bermasyarakat yang masih menjunjung nilai-nilai kehidupan.

Nilai-nilai kehidupan akan berjalan seiring dengan peningkatan pengetahun, keterampilan dan sikap setiap manusia. Pada era modern saat ini, masyarakat dituntut untuk memiliki nilai-nilai kehidupan yang menjadi warisan nenek moyang terdahulu, namun juga dituntut untuk memiliki pegetahuan, keterampilan dan sikap yang sesuai dengan norma masyarakat. Keterampilan merupakan kecakapan hidup yang dimiliki masyarakat untuk memenuhi kehiduapannya dalam bekerja. Dengan keterampilan yang dimiliki maka akan berdampak pada peningkatan penghasilan, pekerjaan, dan kehidupan yang lebih sejahtera di masyarakat.

Kodisi era digital saat ini, tuntutan akan penguasaan teknologi dan informasi sangatlah dibutuhkan. Akan tetapi minimnya tingkat pendidikan dan keterampilan yang dimiliki masyarakat akan menjadi kendala didalam penguasaan teknologi tersebut. Kelurahan Ciparitra Kecamatan Mangkubumi Kota Tasikmalaya merupakan salah satu keluarhan yang terletak di pinggiran kota. Dengan berjarak sekitar $4 \mathrm{~km}$ dari pusat Kota Tasikmalaya. Kondisi ekonomi dan minimnya pendidikan masyarakat, menjadi kendala didalam peningkatan kehidupan masyarakat. Dalam rangka peningkatan ekonomi masyarakat melalui peningkatan kewirausahaan masyarakat di bidang menjahit. Lembaga Kursus dan Keterampilan Anugrah Pratama merupakan mitra yang menyelenggaran peningkatan keterampilan dalam bidang menjahit.

Kendala yang menjadi permasalahan lembaga mitra dalam peningkatan keterampilan masyarakat diantaranya: (1) minimnya tingkat pendidikan masyarakat sekitar, (2) kepercayaan masyarakat bahwa ingin hari ini bekerja 
dan langsung menghasilkan uang, serta (3) rendahnya keterapilan yang dimiliki masyarakat sekitar. Seiring dengan tingkat pendidikan masyarakat yang notabennya membutuhkan peningkatan pendidikan dan keterampilan.

Pendidikan dan keterampilan di era modern saat ini menjadi hal pokok yang harus dimiliki oleh masyarakat. Data BPS Kota Tasikmalaya dalam kurun waktu 2006-2015 menggambarkan bahwa tingkat perkembangan melek huruf mengalami peningkatan yang signifikan mendekati angka $100 \%$ yakni sekitar $99,82 \%$ pada tahun 2015. Akan tetapi pembangunan dibidang pendidikan Kota Tasikmalaya merupakan proses panjang yang hasilnya tidak dapat dilihat atau dirasakan secara instan. Sehingga belum tercapainya angka melek huruf sebesar $100 \%$ dikarenakan masih adanya penduduk usia tua (56 tahun ke atas) yang belum bisa membaca dan menulis karena memang belum pernah mengenyam pendidikan sama sekali (Pejabat Pengelola Informasi dan Dokumentasi, 2015).

Problema rendahnya angka melek huruf di suatu daerah berdampak pada banyaknya pengangguran. Pengangguran merupakan suatu masalah yang memerlukan perhatiaan khusus. Dengan banyaknya tingkat pengangguran pada usai produktif (usia 15 tahun ke atas) maka akan berdampak pada semakin banyaknya kriminalitas, asusila, dan tindakan melanggar hukum. Melalui pendidikan kecakapan hidup di harapkan adanya angina segar bagi masyarakat untuk memiliki keterampilan dan kecakapan hidup.

Pendidikan kecakapan hidup atau life skills menurut (Brolin, 1920) life skills constitute a continuum of knowledge and aptitude that are necessary for a person to fungtion effectively and to avoid interruptions of employment experience. Dengan demikian life skills merupakan pendidikan yang memberikan bekal keterampilan yang praktis, terpakai, terkait dengan kebutuhan pasar kerja, peluang usaha dan potensi ekonomi dan industri yang ada dimasyarakat (Anwar, 2012).

Pendidikan kecakapan hidup merupakan bagian dari pendidikan non formal, dimana pendidikan nonformal adalah jalur pendidikan di luar pendidikan formal yang dapat dilaksanakan secara terstruktur dan berjenjang (Sisdiknas, 2003), lebih lanjut pada pasal 26 ayat 1 Sisdiknas no. 20 tahun 2003 bahwa pendidikan nonformal meliputi pendidikan kecakapan hidup, pendidikan anak usia dini, pendidikan kepemudaan, pendidikan pemberdayaan perempuan, pendidikan keaksaraan, pendidikan keterampilan dan pelatihan kerja, pendidikan kesetaraan, serta pendidikan lain yang ditujukan untuk mengembangkan kemampuan peserta didik.

Pendidikan kecakapan hidup merupakan cakupan dari pendidikan nonformal, karena pendidikan nonformal merupakan pendidikan bagi masyarakat yang memerlukan layanan pendidikan dan berfungsi sebagai pengganti, penambah, atau pelengkap pendidikan formal. Oleh karena itu pada prinsipnya pendidikan nonformal diselenggarakan berdasarkan prinsip dari, oleh dan untuk masyarakat (Presiden RI, 2010). 
Generasi tua yang masih buta huruf rata-rata bekerja sebagai buruh harian lepas. Jumlah penduduk menurut pekerjaan, berdasarkan penduduk yang bekerja, buruh harian lepas merupakan jenis pekerjaan dengan jumlah tertinggi sebanyak 84.899 jiwa $(39,173 \%)$, wiraswasta sebanyak 60.775 jiwa $(28,042 \%)$ (Redaksi, 2017).

Sejalan dengan roadmap LPPM Universitas Siliwangi pada pengabdian masyarakat dengan judul Model Pemberdayaan Masyarakat Melalui Magang Tradisional Dalam Upaya Peningkatan Wirausaha Masyarakat Penjahit di Kecamatan Mangkubumi Kota Tasikmalaya. Judul pengabdian kepada masyarakat ini sesuai dengan tema payung pendidikan yakni peningkatan sumber daya manusia. Serta memiliki SDM yang handal dalam pendidikan dengan memanfaatkan kearifan lokal. Melalui pengabdian ini bersama LPPM sebagai jurusan Pendidikan Luar Sekolah yang bekerajasama dengan LKP Anugrah Pratama dan Forum PKBM Kota Tasikmalaya berusaha untuk meningkatkan keterampilan masyrakat melalui kegiatan pengabdian.

Permasalah yang melatar belakangi analisis situasi untuk diselenggaran kegiatan pengabdian masyarakat di Kecamatan Mangkubumi Kota Tasikmalaya diantaranya sebagai berikut:

1. Masyarakat membutuhkan keterampilan dan pengetahuan untuk memenuhi kehidupan, akan tetapi terkendala dengan pendidikan yang masih minim.

2. Budaya masyarakat yang ingin instan untuk mendapatkan hasil tanpa adanya usaha untuk menigkatkan keterampilan/ kapasitas diri.

3. Kreativitas masyarakat untuk mengikuti kegiatan peningkatan keterampilan diri masih kurang optimal.

\section{METODE}

1. Tahap Persiapan

Pada tahap persiapan yang dilakukan oleh tim pengabdian masyarakat dengan LKP Anugrah Pratama antara lain yakni dengan melakukan observasi pendahuluan lebih lanjut terkait sasaran masyarakat penjahit yang akan mendapatkan pendampingan pemberdayaan masyarakat. Pada tahap persiapan ini mengobservasi dengan seksama terkait permasalah yang dialami oleh masyarakat penjahit. Tahap observasi dengan menggunaan sepuluh patokan dikmas, diantaranya (1) warga belajar sasaran, (2) ragi belajar/ motivasi belajar, (3) sumber belajar, (4) paguyuban kegiatan, (5) pamong belajar, (6) tempat belajar, (7) sarana belajar, (8) dana belajar, (9) program kegiatan belajar, dan (10) hasil belajar. Dengan sepuluh patokan dikmas tersebut, akan memudahkan tim pemberdayaan dalam tahap persiapan pemberdayaan.

2. Tahap Pelaksanaan

Untuk memudahkan dalam pelaksanaan "Model Pemberdayaan Masyarakat Melalui Magang Tradisional Dalam Upaya Peningkatan Wirausaha Masyarakat Penjahit di Kecamatan Mangkubumi Kota 
Tasikmalaya" Tahap pelaksanaan dilakukan dengan beberapa tapah diantaranya:

a) Identifikasi jenis keterampilan yang dipelajari

Pada tahap merupakan identifikasi jenis keterampilan yang akan dipelajari oleh peserta magang, pada tahap ini merupakan tahap rekrutmen peserta magang yang disesuaikan dengan persyaratan calon peserta magang dan perumusana tujuan dan bahan ajar magang yang disesuaikan dengan kebutuhan belajar peserta magang sebagai seorang penjahit.

b) Tahap pelaksanaan

Tahap pelaksanaan kegiatan magang merupakan proses kegiatan pembelajaran didalam pola magang tradisional, pada proses tersebut peserta magang mendapatkan pengetahuan menjahit, keterampilan menjahit yang baik dan bagus, sikap mental wirausaha dalam bidang usaha konfeksi dan wawasan dalam mengelola usaha konfeksi

3. Tahap penilaian

Tahap penilaian magang merupakan evalusi magang selama proses kegaiatan pembelajaran berlangsung, pada tahap ini digunakan untuk mengukur seberapa besar peserta magang menyerap materi didalam pembelajaran magang.

4. Tahap tindak lanjut

Tahap tindak lanjut magang merupakan tahap kesepakatan pengelolaan magang antara fasilitator dengan peserta magang, pada tahap ini peserta magang memiliki tanggungjawab pengelolaan magang yakni mengerjakan tugas dari fasilitator serta hasilnya peserta magang dapat menguasai keterampilan menjahit serta dapat dikembangkan sebagai bekal berwirausaha di rumah peserta magang.

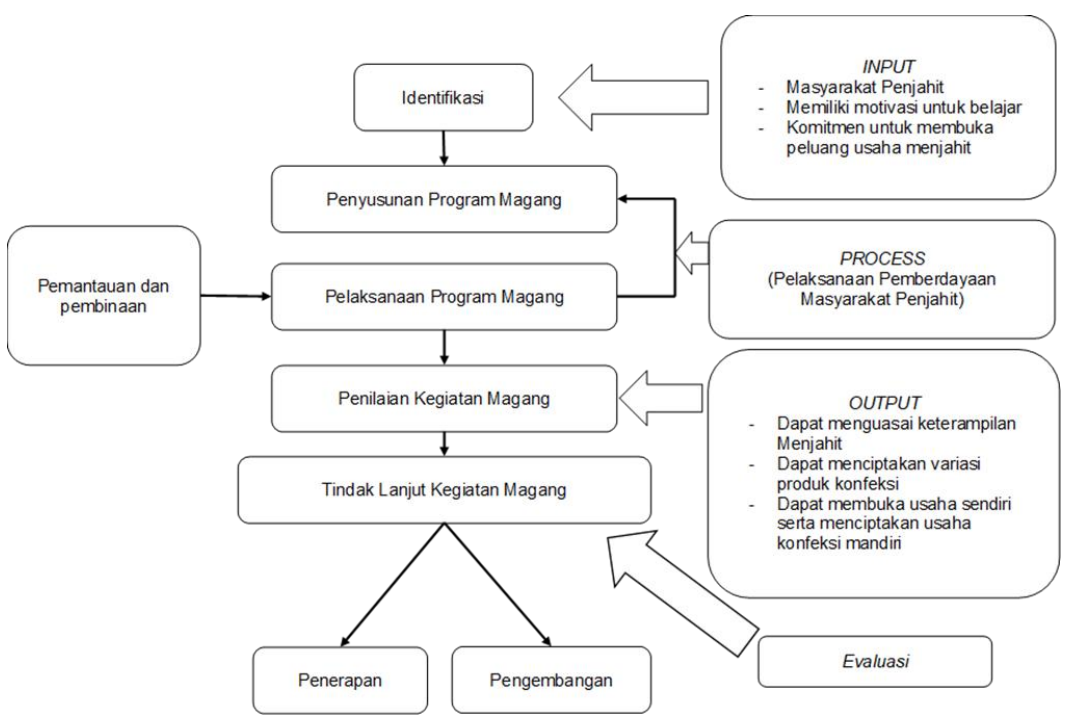

Gambar 1. Desain Pengabdian Kepada Masyarakat Dengan Pola Magang Tradisional 


\section{DISKUSI DAN HASIL}

\section{- Diskusi}

Kegiatan pengabdian kepada masyarakat dengan tema "Model Pemberdayaan Masyarakat Melalui Pola Magang Tradisional Dalam Upaya Peningkatan Wirausaha Masyarakat di Kelurahan Cipawitra Kecamatan Mangkubumi Kota Tasikmalaya". Pada pelaksanaan penyuluhan dan pelatihan dilaksanakan pada lembaga mitra yakni LKP Anugrah Pratama di jalan JI. Raya Singaparna No. 350 Kelurahan Cipawitra Kecamatan Mangkubumi Kota Tasikmalaya.

Kegiatan penyuluhan dan pelatihan magang dilaksanakan mulai tanggal 14 Agustus 2018 sampai dengan 27 Agustus 2018. Pada pelaksanaan penyuluhan dilakukan dalam beberapa tahapan. Mulai dari tahap persiapan, tahap pelaksanaan, tahap penilaian, dan tahap tindak lanjut.

Jadwal kegiatan pemberdayaan masyarakat, pada tahap pertama yakni tahap persiapan, mulai tanggal 14 Agustus 2018 dimana pada tahap ini tim pelaksana bekerjasama dengan pengelola Lembaga Kursus dan Pelatihan (LKP) Anugrah Pratama menentukan peserta pelatihan yang menjadi sasaran dalam pengabdian kepada masyarakat. Peserta penyuluhan sejumlah 35 orang. Peserta penyuluhan semuanya merupakan peserta didik LKP Anugrah Pratama yang tinggal di Kelurahan Cipawitra Kecamatan Mangkubumi Kota Tasikmalaya yang berijazah minimal SMP atau paket B dengan usia antara 1845 tahun.
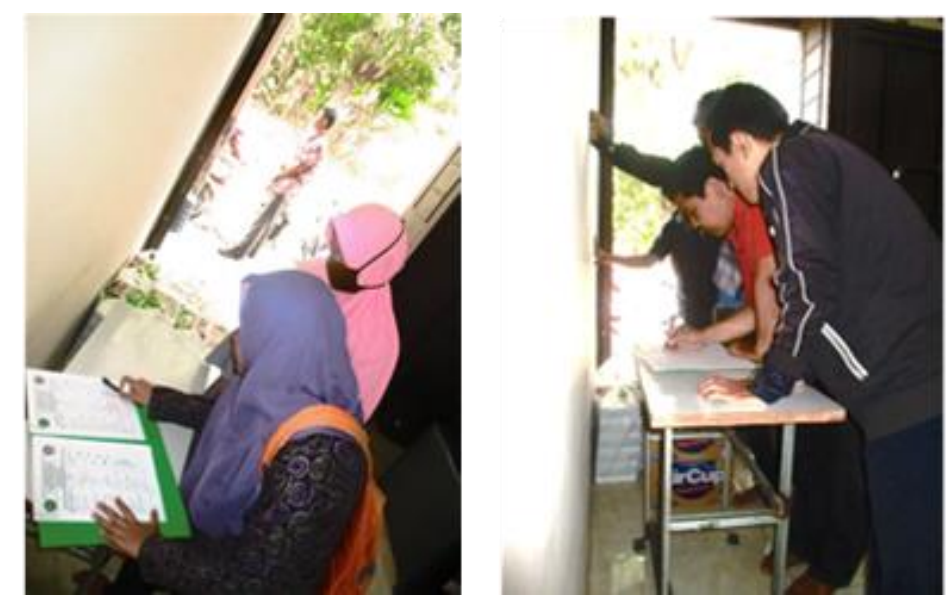

Gambar 2. Peserta penyuluhan sedang mengisi daftar hadir saat kegiatan penyuluhan

Pada tahap selanjutnya tim pelaksana pada tanggal 15 Agustus 2018 dengan lembaga mitra menentukan sumber belajar atau tutor pendamping pembedayaan yang sesuai dengan keterampilan menjahit. Tutor yang menjadi pendamping dalam penyuluhan dan pelatihan merupakan tutor yang sudah menguasai keterampilan menjahit dan memiliki sertifikat pelatihan menjahit.

Sarana dan prasarana dalam penyuluhan dan pelatihan merupakan sarana dan prasaran mitra LKP Anugrah Pratama. Sarana yang digunakan 
diantaranya mesin jahit kecil 20 unit, mesin jahit high speed 18 unit, mesin obras 3 unit, ruang teori (ukuran $4 \times 6 \mathrm{M}^{2}$ ), ruang praktek (ukuran $7 \times 9 \mathrm{M}^{2}$ ), Meja potong kain, dan alat peraga pembelajaran (teori dan praktek menjahit).

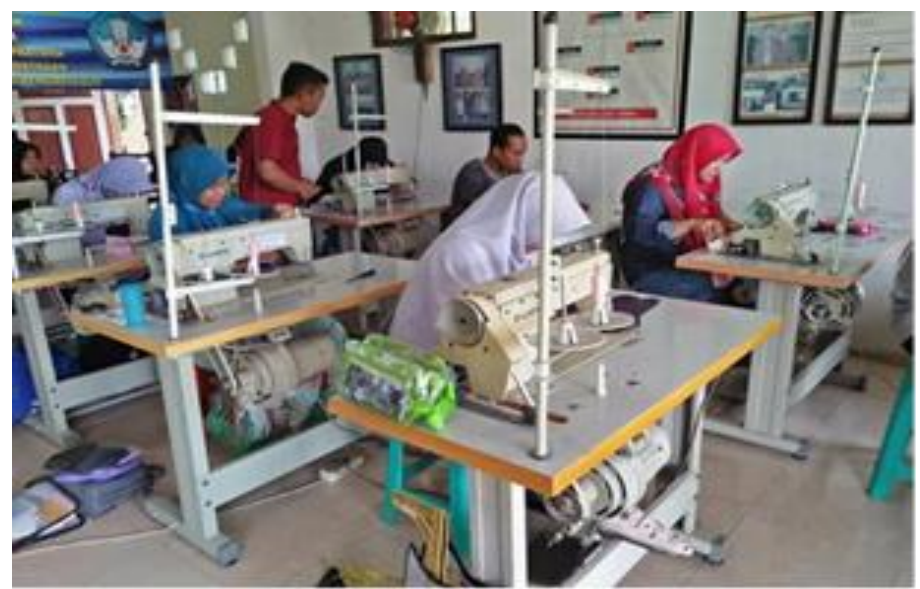

Gambar 3. Sarana dan prasarana menjahit di LKP Anugrah Pratama

Pelaksanaan penyuluhan dilaksanakan selama empat (4) hari mulai tanggal 21, 23, 24 dan 27 Agustus 2018, yakni pada hari pertama (1) Pemaparan teori (sesi pertama Jalan menuju wirausaha sukses, dan sesi kedua motivasi kewirausahaan), pada hari kedua (2) Praktek Menjahit (Cara mengoprasikan mesin jahit, dll), dan pada hari ke tiga dan ke empat (3\&4) magang ditempat penyuluhan selama dua (2) hari.

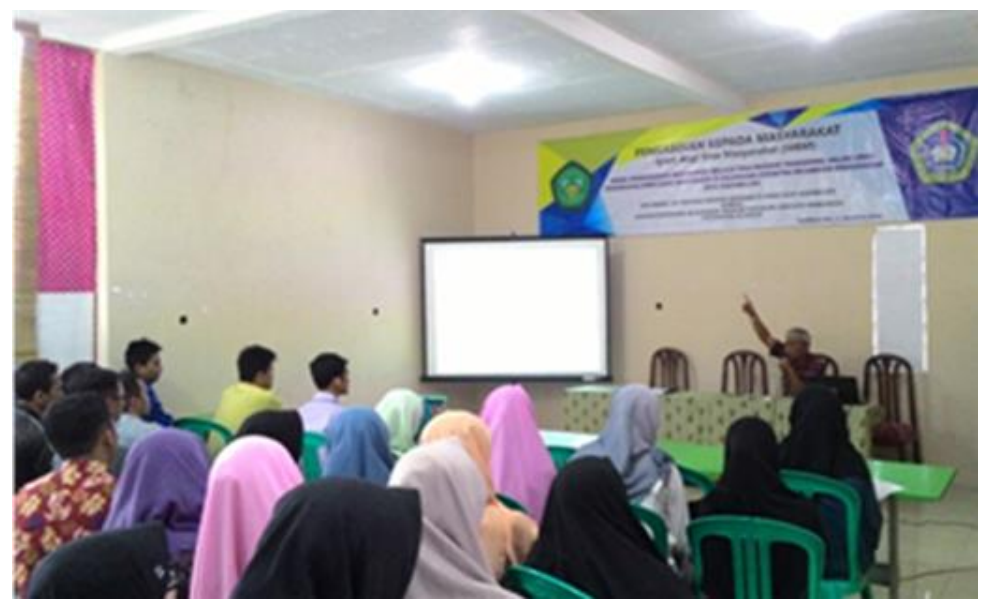

Gambar 4. Pemberian materi sesi pertama oleh ketua pelaksana H. Adang Danial, Drs, M.Kes dengan materi "Jalan menuju wirausaha sukses" 


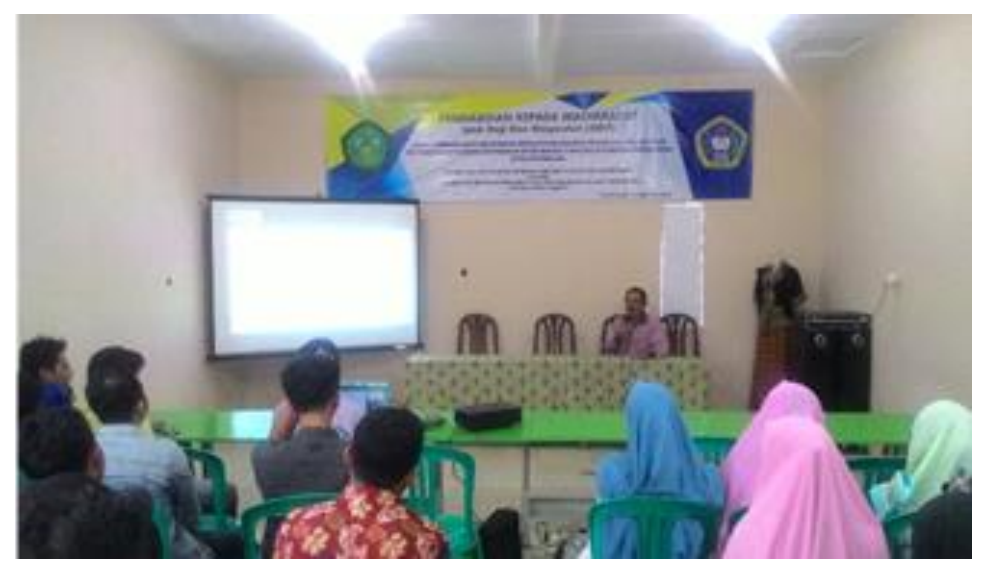

Gambar 5. Pemberian materi sesi kedua oleh anggota pelaksana Prof. Dr. H. Yus Darusman, M.Si dengan materi "Motivasi Kewirausahaan"

Materi penyuluhan dan pelatihan "Model Pemberdayaan Masyarakat Melalui Pola Magang Tradisional Dalam Upaya Peningkatan Wirausaha Masyarakat di Kelurahan Cipawitra Kecamatan Mangkubumi Kota Tasikmalaya" seperti pada tabel 1.1 sebagai berikut:

Tabel 1.1

Jadwal Penyuluhan dan Pelatihan

\begin{tabular}{|c|c|c|c|c|c|}
\hline & Waktu & Kegiatan & Narasumber & Metode & Keterangan \\
\hline 1 & $\begin{array}{l}4 \times 50 \\
\text { menit }\end{array}$ & $\begin{array}{l}\text { Materi } \\
\text { Penyuluhan } \\
\text { 1. Jalan } \\
\text { menuju } \\
\text { wirausaha } \\
\text { sukses }\end{array}$ & $\begin{array}{l}\text { 1. H. Adang } \\
\text { Danial, Drs, } \\
\text { M.Kes. } \\
\text { 2. Mustakim, M.Pd } \\
\text { 3. Prof. Dr. H. Yus } \\
\text { Darusman. Drs }\end{array}$ & $\begin{array}{l}\text { 1. Ceramah } \\
\text { 2. Tanya } \\
\text { jawab } \\
\text { 3. Parti } \\
\text { sipasi }\end{array}$ & $\begin{array}{l}\text { Pendamping } \\
\text { 1. Eulis } \\
\text { Aminatussa' } \\
\text { diyah } \\
\text { (Instruktur } \\
\text { maniahit) }\end{array}$ \\
\hline & menit & $\begin{array}{l}\text { 2. Motivasi } \\
\text { Kewirausaha } \\
\text { an }\end{array}$ & M.Si & & $\begin{array}{l}\text { 2. Epi Patimah } \\
\text { (Instruktur } \\
\text { manjahit) }\end{array}$ \\
\hline
\end{tabular}

Khalayak dan jumlah sasaran peserta penyuluhan yang menjadi sasaran kegiatan "Model Pemberdayaan Masyarakat Melalui Pola Magang Tradisional Dalam Upaya Peningkatan Wirausaha Masyarakat di Kelurahan Cipawitra Kecamatan Mangkubumi Kota Tasikmalaya" ini adalah masyarakat di Kelurahan Cipawitra yang memiliki motivasi untuk belajar dalam bidang keterampilan menjahit sebanyak 35 orang, dengan kehadiran sejumlah 33 orang. Para peserta penyuluhan merupakan peserta didik yang sedang menempuh pelatihan menjahit selama 1 bulan. Sedangkan Sarana dan prasarana yang diperlukan selama penyuluhan berlangsung diantaranya sebagai berikut: Infocus, kursi 40 buah, meja, mesih jahit kecil, mesin lubang kancing, mesin obras, mesin neci, mesin zigzag, mesin high speed, mesin press kancing, mesin potong besar, setrika, white board, meja potong dan kursi. 

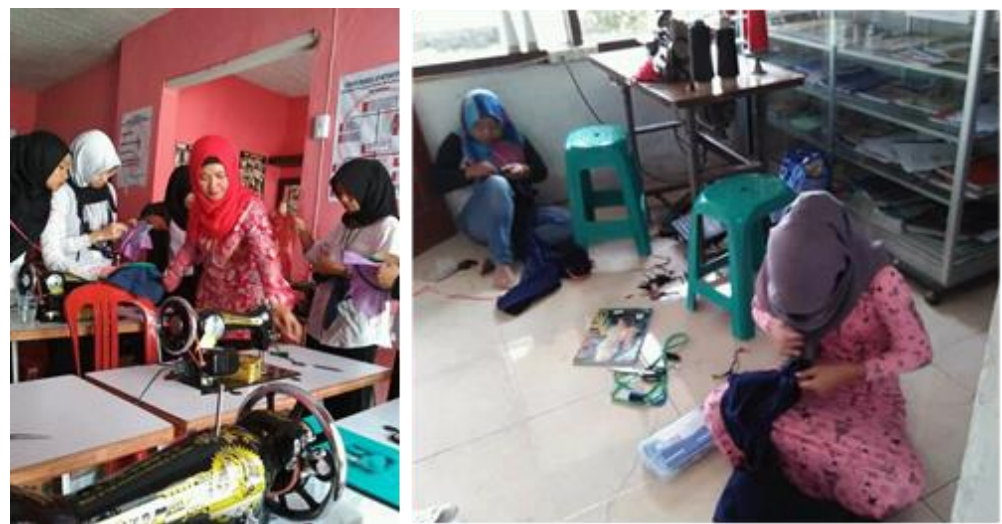

Gambar 6. Fasilitator ibu Epi (krudung merah) sedang mendampingi peserta didik dalam praktek menjahit, dan belajar mengukur kain yang akan di jahit

\section{- Hasil}

Gambaran hasil pengabdian kepada masyarakat yang dilaksanakan pada lembaga kursus dan pelatihan Anugrah Pratama diawali dengan identifikasi, pada identifikasi ini merupakan langkah awal sebagai masukan atau input. Pengabdian kepada masyarakat dengan judul "Model Pemberdayaan Masyarakat Melalui Pola Magang Tradisional Dalam Upaya Peningkatan Wirausaha Masyarakat di Kelurahan Cipawitra Kecamatan Mangkubumi Kota Tasikmalaya". Input atau identifikasi meliputi: (1) masyarakat penjahit, (2) memiliki motivasi untuk belajar, (3) komitmen untuk membuka peluang usaha menjahit.

Pada tahap identifikasi masyarakat penjahit yang sudah terdata sebanyak 35 orang. Namun dalam pelaksanaan kegiatan pengabdian kepada masyarakat yang mengikuti kegiatan pengabdian sejumlah 33 orang, 2 orang tidak dapat mengikuti kegiatan pengabdian karena ada kegiatan yang tidak dapat di tinggalkan.

Dalam persiapan identifikasi sasaran masyarakat penjahit, pelaksana program melaksanakan dengan menggunakan teknik observasi secara mendalam menggunakan 10 patokan dikmas. Pada sepuluh patokan dikmas ini yang menjadi acuan dalam persiapan pemberdayaan kepada masyarakat.

Sepuluh patokan dikmas diantaranya: (1) warga belajar sasaran, atau peserta pemberdayaan dalam kegiatan ini yang menjadi peserta pemberdayaan adalah masyarakat penjahit di LKP Anugrah Pratama sejumlah 33 peserta. Dengan latar belakang seorang penjahit, dan memiliki motivasi untuk mengembangkan usaha menjahit baik ikut dengan konveksi atau dengan membuka lapangan usaha sendiri dirumah masing-masing. (2) Ragi belajar atau motivasi belajar, para peserta pemberdayaan merupakan penjahit yang sedang belajar menekuni usaha menjahit dirumah masing-masing atau tempat konfeksi. Selain itu dalam pelatihan ini ragi belajar yang diberikan oleh pengelola progra dengang sistem maklun, yakni dengan sistem menitipkan mesin di tempat warga belajar, bahan, peralatan, dan bahan garapan di suplai 
dari pemilik usaha konfeksi serta warga belajar tinggal mengerjakan garapan sesuai dengan permintaan pelanggan.

Lebih lanjut, (3) Sumber belajar dalam kegiatan pengabdian kepada masyarakat yang menjadi sumber belajar adalah ibu Epin selaku pemilik LKP Anugrah Pratama dan ibu Euis selaku fasilitator. Serta sumber belajar juga dibantu oleh bapak Doni selaku pengelola kursus dan pelatihan menjahit. (4) Paguyuban belajar, dalam pemberdayaan masyarakat penjahit yang menjadi kelompok belajar adalah Lembaga Kursus dan Pelatihan, sehingga peserta pelatihan dapat belajar dan bertukar pengalaman dengan sesama peserta pelatihan. Paguyuban belajar dalam pemberdayaan masyarakat ini dapat berkembang. Karena program pemberdayaan masyarakat ini juga bersinergi dengan program pemerintah daerah, yakni dengan mewujudkan 5000 wirausaha baru di Kota Tasikmalaya. Oleh karena itu dalam pelaksanaan warga belajar memiliki paguyuban belajar yang luas dan tidak hanya terikat pada LKP Anugrah pratama.

Serta, (5) Pamong belajar dalam proses pengabdian kepada masyarakat yang menjadi pamong belajar adalah tenaga kependidikan Jurusan Pendidikan Masyarakat FKIP Universitas Siliwangi. Dan pamong belajar pada proses pemberdayaan masyarakat ini bekerjasama dengan lintas sektoral yakni pamong belajar Sanggar Kegiatan Belajar (SKB) Kota Tasikmalaya. Karena peserta pemberdayaan sebagian besar adalah peserta pelatihan program kerjasama antara LKP Anugrah Pratama dengan SKB Kota Tasikmalaya dalam rangka mempercepat program wirausaha baru. (6) Tempat belajar, dalam proses pemberdayaan yang menjadi tempat belajar peserta pemberdayaan adalah di LKP Anugrah Pratama. Pemilihan tempat belajar ini karena keterbatasan sarana dan prasarana penyelenggara program pengabdian kepada masyarakat. Oleh karena itu dalam kegiatan ini untuk mendukung kegiatan pengabdian masyarakat Universitas Siliwangi bekerjsama dengan LKP Anugrah Pratama selaku mitra yang memiliki fasilitas peralatan menjahit. (7) Sarana belajar, sarana yang digunakan dalam proses belajar menjahit adalah sarana dari LKP Anugrah Pratama selaku mitra dalam pengabdian kepada masyarakat. Penyelanggara kegiatan pengabdian masyarakat memfokuskan sarana belajar di LKP Anugrah Pratama dengan pertimbangan yakni (a) peralatan mesin jahit untuk praktik di LKP Anugrah Pratama lebih dari 41 mesin, yang terdiri dari 18 unit mesin jahit kecil, 18 unit mesin jahit higt speed, dan 3 unit mesin obras, (b) jarak tempuh LKP dan rumah peserta pemberdayaan masyarakat relatif lebih terjangkau, yakni tidak lebih dari $5 \mathrm{~km}$, (c) peserta pemberdayaan diberikan waktu yang fleksibel dan dapat belajar nyaman di LKP.

Selanjunya, (8) Dana belajar selama kegiatan pengabdian kepada masyarakat dana belajar di dapat dari dana hibah pengabdian kepada masyarakat Univeristas Siliwangi. Serta dana pengabdian ini tidak begitu besar, oleh karena itu dalam program pengabdian kepada masyarakat ini pada implementasinya di sandingkan dengan program kerjasama di Dinas 
Pendidikan Kota Tasikmalaya yakni program percepatan wirausaha baru (WUB) 2018. (9) Program kegiatan belajar, dalam pelaksanaan program kegiatan belajar menjahit peserta pemberdayaan di berikan pendampingan materi kewirausahaan dan motivasi, setelah itu baru diberikan materi praktik menjahit. Kegiatan belajar pendampingan secara teori didalam ruangan dilaksanakan selama 2 hari. Untuk hari pertama yakni peserta pelatihan dibekali dengan materi penyuluhan dengan tema "Jalan Menuju Wirausaha Sukses", dan untuk materi ke dua dengan tema "Motivasi Kewirausahaan". Sedangkan untuk hari ke dua, peserta pemberdayaan diberikan wawasan tentang kegiatan menjahit. Sedangkan waktu yang lain untuk kegiatan praktik menjahit.

Sedangkan untuk yang terakhir, (10) Hasil belajar, dengan adanya kegiatan pengabdian kepada masyarakat diharapkan masyarakat penjahit dapat meningkatkan motivasi berwirausaha, motivasi berkarya, peningkatan keterampilan dan pengetahuan dalam menjahit. Peningkatan motivasi berwirausaha ini diharapkan dapat di implementasikan dalam kegiatan seharihari peserta pelatihan, yakni dengan membuka usaha menjahit dirumah, atau bagi yang tidak memiliki modal dapat menerapkan sistem maklun, dan bisa juga bergabung dengan konfeksi yang memiliki tingkat produksi besar. Peningkatan keterampilan yang terlihat dari peserta pemberdayaa adalah peserta dapat meningkatkan soft skills dan hard skills, misalnya dalam proses pembuatan baju peserta pemberdayaan dapat berkomunikasi ramah tamah dengan pelanggan, serta memiliki kemampuan dalam membuat produk jahitan yang sesuai dengan permintaan pelanggan. Sedangkan untuk peningkatan pengetahuan peserta pemberdayaan terlihat dari peserta dapat mengoprasikan berbagai peralatan menjahit, baik mesin jahit klasik ataupun modern yang menggunakan listrik.

Magang sebagai satuan pendidikan luar sekolah, diperhitungkan mampu meningkatkan kemampuan, keterampilan, dan perubahan sikap warga belajar sebagai pemagang, terutama sikap yang berkaitan dengan nilai-nilai kemandirian, dan dapat dijadikan modal bagi peningkatan kualitas hidup (Kamil, 2003). Dari identifikasi maka di teruskan pada penyusunan program, dan pelaksanaan program magang. Pada tahap ini masyarakat penjahit mendapatkan proses pemberdayaan dan pendampingan selama 4 hari, mulai tanggal 21, 23, 24 dan 27 Agustus 2018. Pada proses pemberdayaan masyarakat penjahit atau peserta pelatihan mendapatkan materi menjahit. Mulai dari pemaparan teori (sesi pertama Jalan menuju wirausaha sukses, dan sesi kedua motivasi kewirausahaan) pada hari pertama (1), Praktek Menjahit (Cara mengoprasikan mesin jahit, dII) pada hari kedua (2), dan pada hari ke tiga dan ke empat (3\&4) magang di lembaga kursus dan pelatihan Anugrah Pratama, selaku tempat belajar peserta pelatihan.

Kegiatan pemberdayaan masyarakat melalui kegiatan pelatihan menjahit ini dimulai dari pukul 08.00-16.00 WIB. Pada pelaksanaan pemberdayaan di masyarakat penjahit, tim peleksana program pemberdayaan juga melaksanakan pemantauan dan pembinaan secara berkelanjutan. 
Sehingga peserta pemberdayaan dalam kegiatan kursus menjahit dapat maksimal. Serta sesuai dengan tujuan dari pemberdayaan masyarakat melalui kegiatan magang di usaha konfeksi. Tujuan magang disini yaitu memberikan pendidikan dan ketrampilan kepada pemagang sambil bekerja dengan waktu yang tidak terbatas. Disini ketrampilan diberikan oleh permagang (orang yang memperkerjakan) bersamaan dengan bekerja (sambil bekerja) (Yoda, 2013).

Sedangkan pada tahap selanjutnya adalah penilaian magang atau output, pada tahap ini merupakan tahap penilaian sejauhmana masyarakat penjahit atau peserta pelatihan pemberdayaan menjahit dapat menguasai keterampilan menjahit. Output yang harapkan selama kegiatan pemberdayaan masyarakat penjahit antara lain: 1) dapat menguasai keterampilan menjahit, 2) dapat menciptakan variasi produk konfeksi, dapat membuka usaha sendiri serta mencitakan usaha konfeksi mandiri. Dengan kemampuan yang dimiliki pemagang maka akan memudahkan pemagang dalam menyerap keterampilan menjahit dari fasilitator. Sedangkan pemagang dapat menciptakan variasi produk konfeksi yakni dengan menciptakan model-model pakaian, gamis, dan baju formal serta model kaos yang dipesan oleh pelanggan. Oleh karena itu dalam pemberdayaan masyarakat atau pemberdayaan perempuan besar harapan dapat meningkatkan pendapatan. Pemberayaan perempuan sering digunakan dalam konteks kemampuan meningkatkan keadaan ekonomi (pemenuhan kebutuhan praktis) individu, yang merupakan pra syarat pemberdayaan (Hikam, 2003).

Dari hasil penilaian ada tindak lanjut kegiatan magang, pada tahap ini peserta pemberdayaan masyarakat penjahit mendapatkan evaluasi secara keseluruhan berkaitan dengan pelaksanaan program dan proses pemberdayaan berlangsung. Dari hasil evaluasi kegiatan pemberdayaan masyarakat penjahit menjadi masukan bagi pemilik kepentingan, apakah hasil kegiatan pemberdayaan perlu diterapkan dan dikembangkan. Hasil penilaian kegiatan magang bahwa peserta pelatihan atau pemagang mendapatkan penilaian yang baik. Mulai dari cara berkomunikasi, peningkatan pengetahuan menjahit, sikap mental berwirausaha dan peningkatan pendapatan. The increase in entrepreneurship community can be seen from the trainees have knowledge of sewing, sewing fast, entrepreneurship mental attitude, and insight in the field of business confection. So they can open business fields to provide for the family (Mustakim, 2017).

Pengabdian kepada masyarakat merupakan bagian dari tri darma perguruan tinggi. Pada pengabdian kepada masyarakat penjahit dengan tema "Model Pemberdayaan Masyarakat Melalui Pola Magang Tradisional Dalam Upaya Peningkatan Wirausaha Masyarakat di Kelurahan Cipawitra Kecamatan Mangkubumi Kota Tasikmalaya". Pada pengabdian kepada masyarakat ini dengan menggunakan model pemberdayaan masyarakat melalui pola magang tradisional, diawali dengan tahap persiapan. Pada tahap persiapan atau identifikasi kebutuhan belajar menggunakan 10 patokan dikmas. Dengan 10 patokan dikmas maka akan memudahkan pelaksana program pengabdian 
dalam menentukan sasaran dan program pengabdian yang akan dilaksanakan. Hal ini sejalan dengan program PLS (Pendidikan Luar Sekolah), bahwa Program pembelajaran dalam PLS di harapkan dapat membantu peserta didik memilih dan mengembangkan wawasan ke-Tuhanan Yang Maha Esa, kemanusiaan yang adil dan beradab, persatuan Indonesia, kerakyatan yang dipimpin oleh hikmat kebijaksanaan dalam permusyawaratan perwakilan, dan keadilan sosial (Kamil, 2012).

Hasil identifikasi kebutuhan belajar menggambarkan bahwa peserta pelatihan menjahit sejumlah 33 peserta, yang memiliki motivasi belajar, dan menetap di Kelurahan Cipawitra Kecamatan Mangkubumi Kota Tasikmalaya. Pada tahap persiapan pemberdayaan masyarakat melalui pola magang tradisional diawali dengan persyaratan pola magang menurut (Anwar, 2012) adalah (a) orang terampil, (b) ada orang atau kurang terampil bersedia belajar sambil bekerja, (c) waktu dan tempat pelaksanaan magang, (d) dana magang, (e) perjanjian kedua belah pihak. Persyaratan pola magang tradisional dengan rincian sebagi berikut:

1. Ada orang yang terampil sebagai sumber belajar, dengan syarat:

a) Bersedia, artinya kesediaan menerima orang lain di lingkungan kerjanya dan bersedia menularkan pengetahuan dan keterampilannya kepada orang lain yang tidak atau belum terampil secara sukarela maupun dengan imbalan.

b) Berkemampuan, yakni memiliki kemampuan untuk mengajarkan keterampilannya kepada orang lain, didasari bahwa tidak semua orang memiliki keterampilan tertentu mampu mengajarkannya kepada orang lain.

c) Berkemauan, selain bersedia menerima sesorang atau lebih untuk belajar sambil bekerja di lingkungan kerjanya, memiliki kemampuan untuk membimbing, juga memiliki kemauan untuk membimbing peserta magang dalam menguasai keterampilan yang dimilikinya sesuai dengan harapan peserta magang.

2. Orang yang tidak terampil atau kurang terampil bersedia sebagai peserta magang (peserta didik), dengan syarat:

a) Memiliki bakat dan minat, keduanya mempengaruhi keberhasilan pelaksanaan magang, bagi seseorang yang mengikuti magang tidak sesuai dengan bakat dan minatnya, kemungkinan besar akan mengalami kesulitan baik dalam proses pembelajaran maupun penerapan pascamagang.

b) Ada kebutuhan, terdiri atas kebutuhan individu peserta magang dan kebutuhan pasar kerja, keduanya perlu dipertimbangkan agara dapat berjalan efektif dan efisien. Artinya kebutuhan individu akan mempengaruhi pencapaian tujuan pembelajaran, sedangkan kebutuhan pasar kerja akan mempengaruhi efektivitas pemanfaaatan keterampilan pascamagang atau pemenuhan pasar kerja. 
c) Kemampuan, terdiri atas kemampuan mengikuti aturan yang berlaku di lingkungan kerja sehingga mereka dapat menyerap pengetahuan, keterampilan dan sikap mental yang ada, maupun kemampuan untuk membiayai dirinya sendiri dalam mengikuti magang.

d) Tujuan yang ingin dicapai, dalam hal ini meliputi tujuan pencapaiaan hasil belajar dan tujuan untuk menerapkan keterampilan pascamagang untuk mengembangkan kehidupannya, dalam arti memiliki pekerjaan tertentu untuk memperoleh penghasilan yanag layak.

3. Tepat dan waktu, tersedia tempat dan waktu pelaksanaan magang (proses belajar sambil bekerja atau bekerja sambil belajar).

4. Dana, dalam perkembangan kehidupan modern kegiatan magang memerlukan dana, seperti biaya transportasi peserta didik, biaya makan, biaya peralatan, dan uang saku sumber belajar dan peserta magang.

5. Kesepakatan atau perjanjian, terdapat kesepakatan antara keduanya baik lisan maupun tulisan tentang aturan pelaksanaan magang, misalnya jangka waktu pelaksanaan magang, kewajiban peserta magang, dan sumber belajar, upah, dan sebagainya.

Berdasarkan persyaratan pola magang tradisional diatas dapat disimpulkan secara umum yakni adanya orang yang terampil dalam hal ini adalah fasilitator dan pemilik LKP Anugrah Pratama. Orang yang tidak terampil dalam hal ini adalah peserta magang atau pemagang. Adanya tempat magang yang dapat digunakan untuk proses pembelajaran magang, dalam hal ini tempat magang di LKP Anugrah Pratama selaku LKP yang bergerak dalam bidang kursus menjahit serta memiliki peralatan menjahit untuk praktik. Adanya dana belajar yang digunakan sebagai keperluan untuk menunjang didalam pelaksanaan magang, dana magang dalam selama kegiatan magang berlangsung dari dana pengabdian masyarakat Universitas Siliwangi. Serta adanya perjanjian antara kedua belah pihak yakni peserta magang dan fasilitator sehingga akan sesuai dengan tujuan pelaksanaan magang yang telah di sepakati bersama.

Langkah-langkah pola magang tradisional menurut (Anwar, 2012) sebagai berikut:

1. Tahap identifikasi jenis keterampilan yang akan dipelajari

Identify the type of skills is an early stage in the determination of the internship program in accordance with the needs of internship participants (Mustakim, 2017). Pelaksanaan identifikasi jenis keterampilan oleh calon peserta magang umumnya berlangsung secara sederhana, karena calon peserta magang berasal dari lingkungan keluarga sehari-hari, berada di lingkungan kerja atau keterampilan yang akan dipelajarinya. Dalam hal pemberdayaan masyarakat ini model pemberdayaan masyarakat melalui pola magang tradisional di Kelurahan Cipawitra Kecamatan Mangkubumi Kota Tasikmalaya, dengan rata-rata usia 18-45 tahun. Dengan profesi sebagai calon penjahit 
Sedangkan identifikasi untuk sumber belajar (fasilitator) terhadap calon peserta magang tidak dilakukan secara ketat, kegiatan magang jenis ini biasanya berlangsung sejak awal, artinya para peserta magang diperkenalkan sejak yang bersangkutan dapat mengikuti keterampilan yang di inginkan. Fasilitator dalam bentuk magang tradisional pada usaha menjahit adalah pemiliki usaha menjahit.

2. Tahap pelaksanaan kegiatan magang

Pelaksanaan magang tradisional berlangsung secara simultan, tidak ada waktu pelaksanaan magang yang sistematis dan terpisah dari kegiatan belajar dan bekerja. Bentuk magang tradisional usaha konfeksi ini, waktu pelaksanaan selama 4 (empat) hari dan disesuaikan dengan banyaknya materi yang diajarkan. Serta tujuan yang sudah ditentukan oleh pengelola program pemberdayaan masyarakat. The purpose of apprentice is for participants to acquire knowledge of sewing, sewing skills, raising mental attitude entrepreneurship, and increasing business insight in a field of confection (Mustakim, 2017).

\section{Tahap penilaiaan magang}

Penilaian magang tradisional terhadap peserta pemberdayaan (peserta magang) dilakukan melalui instrumen pengamatan unjuk kerja peserta pemberdayaan, dalam setiap rangkaiaan kegiatan keterampilan produksi. Penilaian magang pada LKP Anugrah Pratama terhadap peserta pemberdayaan dapat dilihat dari hasil kerja sambil belajar serta kecakapan dan keuletan didalam belajar menjahit. Sehingga penilaian magang dapat secara obyektif, baik dilakukan oleh fasilitator, pemilik LKP ataupun dari pihak pengelola program magang dalam hal ini adalah Dosen Pendidikan Masyarakat Universitas Siliwangi. Selain itu pada tahap penilaian peserta magang juga dapat dilihat dari tingkat kehadiran peserta magang. Assessment of learning internship or internship evaluation conducted by tutors. Tutors come directly to the place to see the internship learning activities and visit their home. While the facilitator evaluates internship participants through attendance data during internship learning. In addition, facilitators assess levels of proficiency, sewing skills, and product results of stitches. A beginner should be expected to master certain fundamental skills in the training program (Mustakim, 2017).

4. Tahap tindak lanjut magang

Tindak lanjut pembelajaran, dapat dilakuakan sejauh mana peserta magang dapat mengaplikasikan keterampilan yang diperoleh melalui kegiatan magang. Penandanya adalah kemampuan peserta magang yang di peroleh pascamagang diaplikasikan melalui kegiatan mandiri di tempat lain dengan membuka usaha menjahit sendiri atau bekerja di tempat magang usaha konfeksi. Follow-up of apprenticeship in the traditional internship pattern namely internship participants can have the sewing skills and can be implemented at their home (Mustakim, 2017). Dengan adanya pengaplikasian keterampilan menjahit yang diterima pemagang selama kegiatan pemberdayaan maka akan membuka peluang usaha dimasyarakat. 
Langkah-langkah pola magang diatas merupakan langkah-langkah kegiatan pola magang tradisional sesuai dengan konsep PLS, karena dalam kegiatan PLS selalu diawali dengan tahap identifikasi jenis keterampilan yang dipelajari, dalam hal ini pada pola magang tradisional jenis keterampilan menjahit, pada tahap pelaksanaan kegiatan magang berlangsung secara simultan (serentak) sehingga pelaksanaan magang di LKP Anugrah Pratama berlangsung secara bersama-sama, pada tahap penilaian disesuaikan dengan kegiatan yang dipelajari sehingga penilaiannya dapat berbeda antara peserta magang yang satu dengan yang lain, serta tahap tindak lanjut magang merupakan tahap peserta magang mengembangkan hasil dari magang untuk di gunakan sebagai modal keterampilan didalam bekerja.

Pola magang tradisional diusaha konfeksi merupakan pola magang tradisional yang menggunakan pembelajaran model konseptual, menurut (Kamil, 2012) model pembelajaran konseptual dapat dilihat pada gambar 7 sebagai berikut:

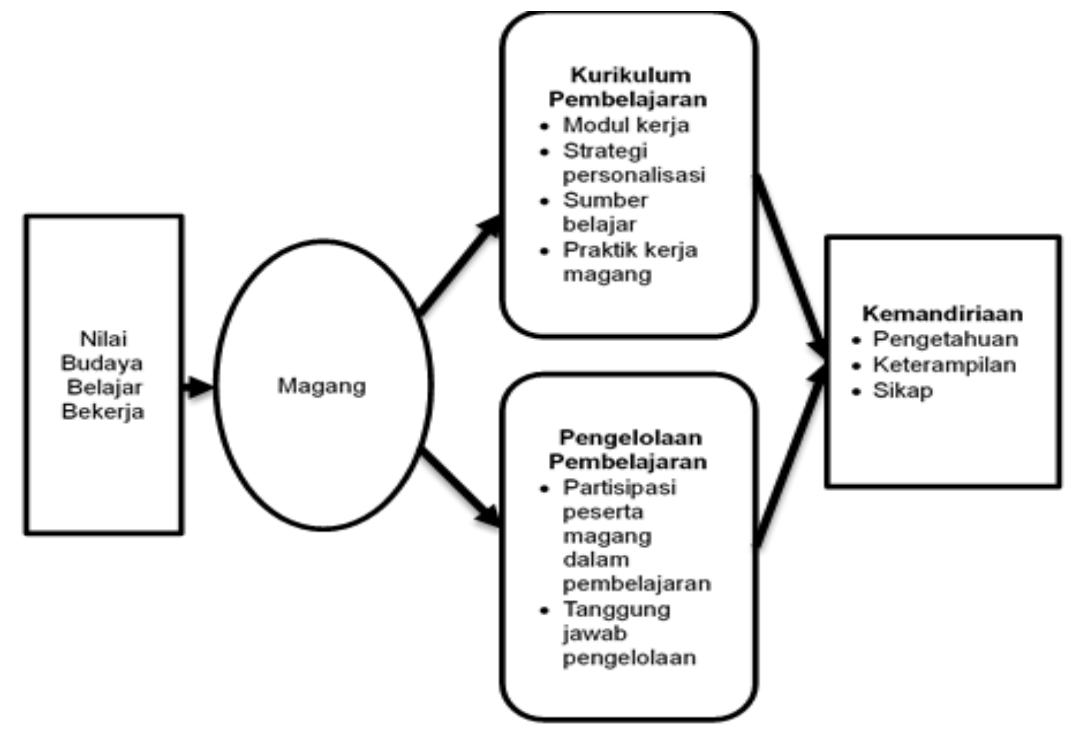

Gambar 7. Model Konseptual Pembelajaran Magang (Kamil, 2012:74)

Model konseptual pembelajaran magang diatas akan diuraikan menjadi kisi-kisi dan sampai diarakan menjadi item-item soal dan instrumen serta indikator-indikator kurikulum pembelajaran dan pengelolaan pembelajaran. Isi kurikulum pembelajaran pada magang tradisional harus disesuaikan dengan tujuan kegiatan magang. Tujuan kegiatan magang ini disusun untuk melandasi rasional menentukan pengetahuan, keterampilan dan sikap mental yang diperoleh selama berlangsungnya proses pembelajaran magang. 


\section{KESIMPULAN}

\section{- Kesimpulan}

Program penyuluhan dan pendampingan pengabdian kepada masyarakat telah terselenggara sesuai dengan rencana kegiatan yang telah disusun. Dengan sasaran sejumlah 33 peserta didik pada lembaga kursus dan pelatihan Anugrah Pratama. Kegiatan pengabdian ini diawali dengan pemberian materi kewirausahaan. Materi penyuluhan pertama Jalan Menuju Wirausaha Sukses, dan materi kedua Motivasi Kewirasuahaan. Kegiatan ini mendapatkan sambutan hangat dari peserta didik. Kegiatan yang dilaksanakan mulai pukul 10.00 WIB dan berakhir pukul 14.30 WIB. Seluruh peserta didik megikuti kegiatan penyampaian materi dengan seksama dan semangat. Pengabdian kepada masyarakat ini diawali dengan adanya tahap identifikasi jenis keterampilan yang akan dipelajari dalam hal ini adalah keterampilan menjahit dengan peserta usia antara 18-45 tahun, tahap pelaksanaan kegiatan magang yang dilaksanakan selama empat hari, tahap penilaian magang pada peserta pemberdayaan dengan menggunakan instrumen pengamatan dan unjuk kerja, serta tahap tindak lanjut magang dengan mengaplikasikan keterampilan menjahit yang diperoleh di tempat usaha sendiri atau konfeksi.

\section{- Saran}

Berdasarkan evaluasi kegiatan pengabdian kepada masyarakat, beberapa saran yang dapat dijadikan masukan untuk kegiatan pengabdian selanjutnya antara lain:

1. Pada kegiatan pengabdian kepada masyarakat perlu ditambah waktu yang lebih banyak, agar peserta didik penyuluhan dapat menerima materi dan praktek lebih lama. Sehingga ada konsekuensi penambahan biaya dalam pengabdian kepada masyarakat.

2. Kegiatan pengabdian kepada masyarakat pada peserta didik dalam bidang menjahit merupakan kegiatan yang memerlukan kegiatan praktek secara berkelanjutan. Oleh karena itu kegiatan lanjutan yang serupa dapat dilaksanakan kembali secara priodik, sehingga mencetak wirausaha baru di masyarakat.

\section{DAFTAR RUJUKAN}

Anwar (2012) Pendidikan Kecakapan Hidup ( Life Skills Education). Bandung: Alfabeta.

Brolin, D. E. (1920) Life Centered Career Education: A Competency Based Approach. Fifth Edition. Virginia. Available at: https://files.eric.ed.gov/fulltext/ED407757.pdf.

Hikam, M. R. (2003) "Peran Fasilitator Magang Batik Jonegoroan Dalam Pemberdayaan Perempuan Ibu Rumah Tangga di Pusat Magang Batik Mak Ni Desa Jono Puro Kecamatan Temayang Kabupaten Bojonegoro," pp. 1-10.

Kamil, M. (2003) “Model Pembelajaran Magang Bagi Peningkatan Kemandirian 
Warga Belajar: Satu Pendekatan Baru," DinamikaPe, p. 13.

Kamil, M. (2012) Model Pendidikan dan Pelatihan;Konsep dan Aplikasi. Bandung: Alfabeta.

Mustakim (2017) "Traditional Internship Pattern in Developing Community Enterpreneurship," 88(Nfe 2016), pp. 214-217. doi: 10.2991/nfe16.2017.56.

Pejabat Pengelola Informasi dan Dokumentasi (2015) "Pemerintah Kota Tasikmalaya." Available at: https://www.portal.tasikmalayakota.go.id.

Presiden RI (2010) "PP RI No. 17 Th. 2010 ttg Pengelolaan dan Penyelenggaraan Pendidikan," pp. 1-215. doi: 10.1017/CBO9781107415324.004.

Redaksi (2017) "Perkembangan Data Kependudukan Kota Tasikmalaya," Cameon Cakrawala Media Online. Available at: https://www.cakrawalamedia.co.id/inilah-perkembangan-datakependudukan-kota-tasikmalaya/.

Sisdiknas (2003) Sistem Pendidikan Nasional. Jakarta.

Yoda, P. (2013) Model Pembelajaran Magang, Model Pembelajaran Magang. Available at: https://lib.unnes.ac.id/17115/. 